\title{
Stress Dynamic of College Students
}

\author{
Bau Ratu \\ Tadulako University \\ Palu, Indonesia \\ bauratu74@gmail.com \\ Syamsu Yusuf \\ Tadulako University \\ Palu, Indonesia
}

\author{
Iskandar \\ Tadulako University \\ Palu, Indonesia
}

\begin{abstract}
This research intended to describe stress dynamic of college students of Guidance and Counselling Study Program, Faculty of Teacher Training and Education, Tadulako University. The number of subjects was 3 college students. This research was using qualitative methodology. The results described stress dynamic that all of the subjects had experienced in their daily life. Stress dynamic included internal and external stressor, physical and interpersonal symptom of stress, emotional and problemfocused coping stress.
\end{abstract}

Keywords—stress dynamic, stressor, stress symptom, coping stress.

\section{INTRODUCTION}

Coping stress was very necessary to balance somebody life. The coping stress was an action to change cognitive and behavior constantly to reduce and tolerate the stressor both internal and external can cause stress. Coping stress gave the opportunity to an individual for doing constructive change in repair and life improving. Basically coping stress was the ability which could be trained and increased deal with the environment. Coping stress has several different strategies which depend on individual adaptive judgment, and coping stress' ability will effect on judgment change as well as positive and negative action.

In life institution (university) context, students had coping stress' ability adequate will change judgment, by positive action and the students will positioning "stress" as a stimuli, and distributed their own resources on demands of academics such us having a problem directly, judging or stress condition perception by rationally, self-control, completed the assignment, be punctual, improved self-ability, motivated and competence, despite problem faced was quite complicate [1-4].

The coping stress' ability adequate was a mechanism which can help a challenge or stressor threatening [5]. In practice, students run their life is not always smooth, many obstacles which was faced both academic and nonacademic, pertinent transition period from high school to an university that will face and move to a bigger academic structure, more interpersonal, more academic press to get achievement, career, social press can cause students feel stress [6-8].

Ref. [9] stated demands of academic at university became source stress such us learning activities to force had more time than senior high school, less of self-study, lack of competence to do assignment, inappropriate to choose a major, to remedial value was not pass, the relation between lecturer and students are not harmonic so that it was not able to finish the last examination.

Abouserie stated [1] demand of academic and examination which become a source of stress for students, they felt the stress of academic such us students had to master all subjects in shortterm and complete the assignment on time [10]. The further demand of nonacademic can also source of stress pertinent to a friend of the same age or couple, living cost, lecture, accommodation, the location of the campus learning facilities.

According to[2] students who are having stress will response as a threat (dangers) for themselves, too broke their selfconception and to fail their desire and necessity of self. Stress refers to pressure burden in life and the interaction between individual and environment, ranked individual demand to assess the resources available welfare and harm [2] [5].

Stressor threatening is the state of being considered unbalanced between demand facing respond the individual to the demands (coping stress). Inability students are doing coping stress diverse demands academic and nonacademic will have a negative impact on study resolution that can cause they respond to the problem in a destructive manner [11]. The destructive shown students interesting of behavior or escape from stress, characterized by a) ditching collage inferiority, b). Feeling helpless, c).indulge oneself, d).denounced yourself, e).often reflect negative, f). defends mechanism [9] stress prolonged and fatigue do coping stress have consequences serious and disorder physical and psychological (cause, burn out, depression and suicidal) [12-17].

The result of study American colleges health association 2006, in [18] said that stress at academic as the greatest obstacle to achieving the academic performance. The research was done with 97.357 students show $32 \%$ the ability coping stress students inadequate, which have resulted not able to solve their jobs well and received achievement lower and inability coping stress threatening they had to drop out cause unsettle in the resolution of the study. A year later conducted [19] found the same result of the impact of inability the students are doing coping stress and the stress was not managed will affect the physical, emotion, 
behaviour and mind, as the changes for the family context, social, school, their peers and community [3] [20].

Demands environment faced by students put pressure that cause a source of stress and students having judgment and the ability coping stress different [2] This difference is perception of the particular events have on impact on how assessment cognitive students in the interpretation of events Sanders \& Woll, in [17] Judgment can perceive positive or negative by the student's concern and judgment depending on the ability of students in choose a coping stress students. Students who have a coping inadequate possible way of this assessment negative and pressure stress felt heavy, in contrast, who have coping sufficient the possibility of this assessment positive way and pressure stress felt good and effective, thus stress it can be minimized.

Students who have coping stress inadequate, basically need counseling [21]. Service counseling given as an effort to help students in increase coping stress faced effort to improve coping stress students is something should be critical attention from college include supervising academic lecturer (pa.Guidance and counseling). Guidance counseling department has the assumption that healthy development happened through healthy interaction between students and environment.Thus the development individual the environment is the strategy of the development of counselor [22]

The development environment is more focused on learning environment structured deliberately in designed for a given change to individual studies the behavior, and development of the ability of an individual reaching success optimally (related to personal aspect, social, learning/academic, and carrier [23]. Guidance counseling realize education function to help the students be aware of their potential, refine, internalization, renew, integrated judgment system which occurs congruent into pattern behavior independent [24]. This effort to help the individual through guidance counseling needs methods and psychological technique for facilitating individual behavior.

\section{METHODS}

\section{A. Method}

Based on the issue which researched and objectives, the researcher used qualitative methods. Bog and Taylor in [25] define qualitative methods as procedures of the researcher can produce a description like word written, verbal from the people which are researched.this approach refers to individual background holistic, in this case, should be not isolated individual or organisation into variable or inscription, but it is a part of nee.

\section{B. Participants}

The research was conducted by students with purposive for understanding the participants characteristic, such as:

- The students are doing their thesis which is having in big academic structure, more impersonal, additional pressure to get the achievement, career, and social pressure.

- The students can be identified who has coping stress, low level, middle, based on the result of measurement by using an instrument coping stress.
- The students who didn't have any competence yet, doing coping stress facing the stressor.

\section{Data Analysis}

In this research, the researcher act as the main research instrument within collecting data [26]. The researcher big dealt with the whole process of doing research at the beginning of choosing a title, topic approach, collecting data, data analysis, and introspection. This research applies to interview and observation.

It was different with quantitative, qualitative research has not a formula to process and analyze the data.Patton in [26] state there was one point to remember is must be monitoring and report the process and procedure of data analysis honestly. The step of data analysis in this research namely data reduction, data presentation, and conclusion.

\section{RESULTS}

This research conducted at Tadulako University in Palu, particularly Guidance of counseling department at Faculty of teacher training and education at Campus on Tadulako Tondo Palu. The researcher observes many students are not able to complete their thesis on time and tend to be longer in organizing thesis. It is because of stress faced by the students in organizing their thesis. When the stress can be not solved will disturb the lecture what the students are doing. It is one reason become the program of guidance of counseling as research.

Dynamic stress has these points :

1) Stressor: internal (the nature of subject easy panic and worrier external (supervising lecturer difficult understood, friends mocking, relation couple was not conducive.

2) Symptom stress: a headache, stomach, less repetitive, acute gastritis, lazy to do something, lazy to meet someone. 3) Coping stones real: emotional concern (confused, panic, worry, don't know what to do, sharing, sleep)

Result of coping stress real: when panic is not produced anything, but when sharing the subject is more clear up so can solve problem

4) Coping stones ideal: subject want to solve problem calmly and no panic again, the subject want to think to clear up to find the solve problem (problem-focused coping).

\section{CONCLUSIONS}

Coping stress will become effective and realistic accordance with increasing age, it was because of the cognitive process change of experience, response to the situation stress [2]. Coping stress balance students, in acting change cognitive and behavior as well as reduce, tolerate the problem, pressure that threatens in this life.

Factor supervising who are less of effort to reach out to whole students who will guide in the thesis is a stressor external seriously impact for the subject R and NJ.Factor relation with girls/boyfriend will be one external stressor contribute to stress experienced subject NJ.

While internal stressor has influenced the emergence of sign stress all the subject. The subject of $\mathrm{R}$ have the perception of a negative a women, he considered the women weak. Less smart and like gossiping. Erroneous perception about this 
women can cause subject $\mathrm{R}$ stress of inevitably he had to interact with the women, though he always confines ourselves and avoids interaction with women and more to do with the men. The personal NJ always worry and easily panic.

\section{REFERENCES}

[1] Nandamuri \& Gowthami. (2013). Sources Of Academic Stress - Study On Management Students. ITM Business School; Hunter Road, Warangal: India, pp. 31-42.

[2] Lazarus \& Folkman. (1984). Stress, Appraisal, And Coping. New York: Springer Publishing Company.

[3] Doman, Beck (2014) Stress In College. Community College Journal of Research \& Practice, pp. 3-4.

[4] Yusuf, Syamsu. (2009). Mental Hygiene. Bandung: Maestro.

[5] Pereira, P. (2013). The Stress of Life: Understanding and Managing Stress. Stress Booklet.

[6] Santrock, J.W. (2003). Adolescence, sixth edition. Alih Bahasa Adelar \& Saragih. Adolescence, edisi keenam. Jakarta: Erlangga.

[7] Wilks, S. E. (2008). Resilience A Mid-Academic Stress: The Moderating Impact Of Social Support Among Social Work Students. International Journal Of Social Work, 9(2), pp. 106-125.

[8] Howe, H. Isabelle (1993) Effects Four Day and Five-day academic weeks on stress and depression levels in the gifted secondary student. (Dissertation) Texas: Faculty of Texas Tech University.

[9] Roberson, J. B. (1985). The Effect Of Stress Inoculation Training In A Classroom Setting On State-Trait Anxiety Level And Self Concept Of Early Adolescents. (Dissertation). Texas: Graduate Faculty Of Texas Tech University.

[10] Stepherd, James F. (1987). College Study Skills (Queensborough Community College. The City University of New York Third Edition). Boston: Houghton Mifflin Company.

[11] Kate, Kulkarni, Shetty, Deshmukh \& Moghe. (2010). Acknowledging Stress in Undergraduate Medical Education and Methods if Overcoming It. Current Research Journal of Social Science, 2(5), pp. 282-287.

[12] Chen et al. (2013). The Impact of Academic Stress on Medical Student Attending College in The Inner Mongolia Area of China. Open Journal of Preventive Medicine, 3(2), pp. 149-154.
[13] Calaguas, G. (2011). Curriculum And Sex-Specific Differences In Academic Stress Arising From Perceived Expectations. International Journal Of Human And Social Sciences, 6(1), pp.63-66.

[14] Chapman, David. W et al... (2007). Academic Stress of International Student Attending U.S. Universities. Research in Higher Education. Vol.33 (5).

[15] Wen, C. (2013). A Study of Stress Sources Among College In Taiwan. Journal of Academic and Bussines Ethics, pp 1-8.

[16] Schraml, Perski, Grossi, Makower. (2012). Chronic Stress and Its Consequences on Subsequent Academic Achievement among Adolescents. Journal of Educational and Developing Psychology.2(1), pp. 69-79.

[17] Santrock, J. W. (Eds 2). (2007). Child Development, eleventh edition. (Perkembangan Anak). Jakarta: Erlangga.

[18] Misra, R \& McKean. (2000). College Students' Academic Stress And Its Relation To Their Anxiety, Time Management, And Leisure Satisfaction. American Journal of Health Studies, Vol. 16(1), pp. 41 http://classroom.synonym.com/academic-stress-itsrelation-anxiety-college-students-2777.html

[19] Pierceall, Emily A., and Marybelle C. Keim (2007). "Stress and Coping Strategies Among Community College Students." Community College Journal of Research \& Practice 31 (9), pp. 703-712

[20] Kusz, M. (2009). Stress In Elementary School. (Theses). Northern Michigan University.

[21] Calaguas, G. (2013). Parents/Teachers And Self-Expectations as Sources of Academic Stress. International Journal of Research Studies in Psychology, 2(1), pp. 43-52.

[22] Rao, A.S. (2008). Academic Stress and Adolescent Distress: The Experiences of $12^{\text {th }}$ Standard Students In Chennai, India. (Dissertation) India: University of Arizona

[23] Peterson. Gary W., Robert \& Myrick. (1995) Florida's School Counseling and Guidance Framework: A Comprehensive Student Development Program Model. This document was first published in 1995 by the principal authors: Florida State University.

[24] Kartadinata, Sunaryo (2011) Menguak Tabir Bimbingan dan Konseling Sebagai Upaya Pedagogis. Bandung: UPI Press

[25] Wan, Chapman \& Biggs. (1992). Academic Stress of International Students Attending U.S Universities. Research in Higher Education. Vol.33 (5). 